\title{
PERSONALITY AND SELF-REGULATION AS DETERMINANTS OF RATIONAL DECISION MAKING IN A POLITICAL VOTING SITUATION
}

\author{
Tatiana A. Indina, \\ Varvara I. Morosanova \\ Psychologial Institute of Russian Academy of Education \\ Moscow
}

The association of self-regulation and personality factors with rational decision making was investigated using an experimental model of political voting. The results revealed different sets of personality characteristics for rational and emotional voters. A self-regulation/personality typology of decision making was then constructed, and traits representing self-regulation, cognition, and personality were examined as predispositions toward rational decision making. As a result, specific connections among these variables were uncovered, through which the primary role of the conscious self-regulation system in the management of rational decision making in a political voting context was established.

Keywords: decision making, choice, rationality, emotionality, self-regulation, personality traits, psychological determinants, typology.

\section{Introduction}

The sophistication of and contradictions among social-psychological processes in the political sphere have created cognitive barriers to the rational understanding of social and political reality. These barriers lead to attitudes and perceptions of political processes that are based on emotion.

In contemporary Russian politics, election results determine the future development of the country. This fact makes the study of voter behaviour extremely important for Russia. Ordinary voters find it difficult to orient themselves to the never-ending voting process. They must decide whether to vote, and if so, which candidate to vote for. These choices are determined by a variety of factors, primarily psycho-

The research was supported by Russian Humanitarian Scientific Foundation. Project N 07-0-00882a and Grant of President of RF for young scientists, N MK-6133.2008.6. 
logical ones. The most important of these psychological determinants of rationality-personality and self-regulation, must be analyzed in this context. We aim to answer two questions in this study: First, to what degree are voters' choices rational or emotional; that is, do people vote mostly with their mind or with their heart? Second, which psychological traits do rationality depend on? For this research, we define decision making as choosing one of several alternatives in a political voting situation.

We propose that the conscious self-regulatory system plays the key integrative role in decision making by linking cognitive factors with personality factors. The present research is conducted within the framework of the individual styles of self-regulation theory (Morosanova, $1991 ; 1995 ; 1998 ; 2002 ; 2003 ; 2006)$. It continues the research of the Self-Regulation Laboratory of the Psychological institute RAE. The lab is devoted to the study of specific manifestations of self-regulation in research subjects and how personality traits and regulatory mechanisms influence conscious behaviour.

From the methodological standpoint, we have adopted the subjective approach to human psychological functioning developed by researchers such as S.L. Rubinshtein, K.A. Abulkhanova-Slavakaya, A.B. Brushlinsky, O.A. Konopkin, and A.V. Petrovsky. In this approach, conscious selfregulation is defined as a systematically organized psychological process of initiation, organization, support, and management of all external and internal activity which is goal-oriented (Konopkin, 1995; Konopkin, and Morossanova, 1989). In the present research, we have applied this subjective approach in an attempt to discover the intellectual, personality, and self-regulatory factors that can predict rational decision making.

A great number of works have been devoted to the self-regulation aspect of decision making. In particular, the Russian psychologists A.V. Karpov and T.V. Kornilova have made important contributions to the development of the self-regulation approach to decision making and stressed its importance.

Decision making has been conceptualized as voluntary self-regulation by authors such as V.A. Ivannikov (1991), I.P. Pavlov, D.N. Uznadze (1996), S.I. Shartishvili, L.M. Vekker, A.C. Puni, V.I. Selivanova, G.L. Tulchinsky, D.A. Leontiev, and E.P. Ilyin; in terms of goal-orientation and goal-achievement by A.R. Luria, E.D. Khomskaya (1976), O.K. Tikhomirov (1977), X. Hekhauseh (1986), and K. Levin; in terms of the social-psy- chological vectors of self-regulation by G.M. Andreeva (1994), S. Gallam, and S. Moscovici (1992); and in terms of voluntary control by L.S. Vygotsky (1982). O.K. Tikhomirov has studied the motivational and emotional aspects of cognitive self-regulation, and the motivational mechanisms of decision making have been stressed by V. Edwards (1954).

T.V. Kornilova combines the approach of connection with personality-motivational variables as determinants of decision making strategies. She defines rationality as the readiness to think over one's decisions and to act with possibly incomplete information. O.K. Tikhomirov, A.M. Matushkin, A.V. Brushlinsky, and D.B. Bogoyavlenskaya conceptualize rational cognitive activity as a form of self-regulation.

The theoretical review prevented above allows us to propose an interrelation between the rationality of decision making and individual selfregulation, personality, and cognitive traits. We also propose that this interrelation is causal. The aim of our study was to discover cognitive and personality predictors of rational decision making in political voting. Our data collection in the Self-Regulation Laboratory was based on the assumption that the development of self-regulation plays the leading role in the generation of rational decisions, and that it underlies the influence of personality and cognitive resources on decision making.

From the standpoint of the theory of conscious self-regulation, we define rationality as the self-regulatory component of decision making. It manifests in the conscious comparison of alternatives for achieving personal goals, the search for the information needed to analyse meaningful internal and external conditions, the selection of cognitive tools for implementing the decision, and the conscious prediction of the consequences of the decision.

\section{Method}

There were 290 participants (136 men and 154 women), ranging in age from 18 to 65 years. All were students and potential voters.

\section{Procedure}

Our measurement of the rationality of decision making was based on an elaboration of the political voting model discussed above. This model provides an understanding of the rationality of decision making in a political voting situation in which the "electorate" is provided with a choice between two political candidates. The model allows us to understand the 
specific decision-making processes. Why the subjects/voters chose one candidate or the other was assessed through written self-reports. Before voting, the subjects had to read each candidate's campaign material, which included a biography, a photo, an appeal to the electorate, and a political program.

This campaign material was designed to present one of the candidates as rational and the other as emotional. For the rational candidate, the political program was described in detail, but the biography included only important information and facts about the candidate's life. The appeal to the electorate was business-like and concrete. In the photo, the candidate appeared strict and formal. The emotional candidate was projected as emotional and expressive. The appeal to the electorate was warm, and the political program was patriotic and short on specifics. In the photo, the candidate was smiling. In short, the description of the rational candidate was aimed primarily at the voter's mind whereas that of the emotional candidate was aimed primarily at the voter's feelings. The constructed images of the two candidates were equal in terms of political orientation and physical attractiveness.

The subjects were asked to vote for one of the two candidates and explain their choice by answering the question, "Why did you choose this candidate?" The winner was the candidate who received the largest number of votes.

We expected that rational voters would be more oriented toward analysing and evaluating the concrete facts in the candidates' political programs and biographies. We expected the emotional voters to be more sensitive to the expressiveness of the text and the emotionality it conveyed. We also expected them to pay more attention to each candidate's personality and appearance, and that they would choose mainly on the basis of feelings and emotion.

To evaluate the subjects' rationality, their self-reports were submitted to qualitive and quantitive content analysis, as well as evaluations by professional psychologists. A number of criteria have been developed for assessing rationality and emotionality. The subjects received a score from 1 to 5 for the rationality and emotionality of their decision making

We also analysed motivation. To estimate the subjective significance of their voting, the subjects were asked two additional questions: "Do you regularly take part in political voting?" and "Do you consider your vote important? (Do you think your vote influences the results?)”.
Rationality in decision making was assessed in terms of four parameters: 1) the choice of candidate, 2) the degree of rationality, 3) the qualitative characteristics of the rationality or emotionality, and 4) the subjective significance or importance of the voting procedure to the subject.

Thus, two types of rationality were tested: rationality as a personality trait (which we call general rationality) and rationality in decision making.

\section{Measures}

To measure self-regulation, the following tests of personality and cognitive processes were used: the "Standard Raven's Progressive Matrices", the "Personality Decision Making Factors" questionnaire, D. Keirsey's "Personality Type Indicator," E.P. Ilyin's “Characteristics of Emotionality" questionnaire (to measure self-evaluation), and the "Self-Regulation Questionnaire" of V.I. Morosanova.

\section{Statistical tests}

Bivariate correlations, factor analysis, cluster analysis, and regression analysis were used to analyze the data. We used Statistica-6 and SPSS-13 statistical software.

\section{Results and discussion}

\section{The rationality of decision making in political voting}

Of the 290 subjects, 155 (54\%) voted for the rational candidate, $84(29 \%)$ voted for the emotional candidate, and $51(17 \%)$ voted "against all."

The 10 experts who evaluated the rationality/emotionality of the subjects' self reports divided the sample into two extreme groups: 57 subjects were classified as highly rational in their decision making, and 50 were classified as highly emotional in their decision making. In the high rationality group, $54 \%$ voted for the rational candidate, $28 \%$ voted for the emotional candidate, and $18 \%$ voted against all. In the high emotionality group, $46 \%$ voted for the emotional candidate, $30 \%$ voted for the rational candidate, and $24 \%$ voted against all (Figure 1 ). Thus, there was a tendency for subjects to prefer the candidate with the same rationality/emotionality as themselves. This tendency was greatest for those subjects who considered their participation in the voting process to be important and significant. 
High rationality group

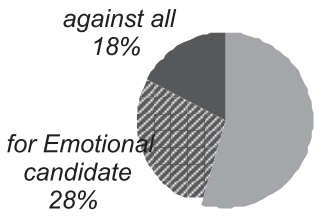

for Rational $54 \%$

$28 \%$

High emotionality group

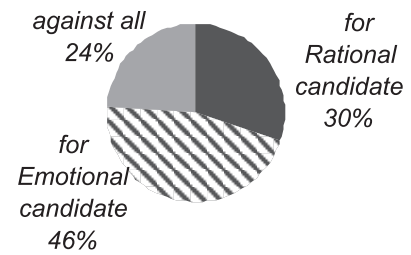

$46 \%$

Figure 1. Distribution of voices for each candidate in groups of rational and emotional subjects

\section{Content analysis of subjects' thought processes in voting}

Neither the choices of the rational candidate nor the evaluations of the psychologists are sufficient as measures of the subjects' rationality. Thus, the next step to apply content analysis to the self-reports as a way to compare the linguistic characteristics of the rational and emotional choices (see Table 1).

This qualitative and quantitative content analysis led to the identification of typical words and word combinations that might serve as

Table 1

The rationality and emotionality of the subjects' choices

\begin{tabular}{|c|c|}
\hline Emotional choice & Rational choice \\
\hline $\begin{array}{l}\text { - Estimation of the candidate's } \\
\text { personality, based on discussion } \\
\text { of voting in general, politics, the } \\
\text { world, and society in general. } \\
\text { - Citing anecdotes and stories in } \\
\text { the explanations. } \\
\text { - Expressing personal impres- } \\
\text { sions of the candidate's appear- } \\
\text { ance in the photo. } \\
\text { - Using emotional language in } \\
\text { the reports (e.g., slang, analogies, } \\
\text { epithets, metaphors). }\end{array}$ & $\begin{array}{l}\text { - Concrete details (e.g., facts, examples) in } \\
\text { the political program and biography. } \\
\text { - Comparative analysis of the candidate's } \\
\text { program and biography. } \\
\text { - Analysis of the style and structure of the } \\
\text { language used. } \\
\text { - Statement of the subject's own political } \\
\text { position and estimation of its correspondence } \\
\text { to the candidate's program. } \\
\text { - Critical evaluation of the information } \\
\text { provided. } \\
\text { - Extraction of the main points in the candi- } \\
\text { date's presentation. }\end{array}$ \\
\hline $\begin{array}{l}\text { - Diffusion and lack of concrete- } \\
\text { ness in the statements. }\end{array}$ & $\begin{array}{l}\text { - Logic and concreteness of subject's presen- } \\
\text { tation. }\end{array}$ \\
\hline
\end{tabular}

markers of highly rational or emotional decision making. For example, the reports of the rational voters contained many instances of such linguistic structures as evaluative statements, a professional lexicon, and nouns expressing action. The reports of the emotional voters were typified by an emotional lexicon, descriptions of their own emotions and attitudes towards the candidate, patriotic language, slang, and evaluation of the candidate's physical appearance.

Thus, the application of the political voting model has allowed us to distinguish groups of subjects with highly rational and highly emotional decision-making styles and, through an analysis of their self-reports, to describe the characteristics of the rational and emotional thought processes that led to their choice of candidate.

\section{The self-regulation, personality, and cognitive}

characteristics of the rational and emotional subjects

Student $\mathrm{t}$-tests were used to compare the extreme rational and extreme emotional decision-making groups with respect to their specific self-regulation, personality, and cognitive traits (see Figure 2).

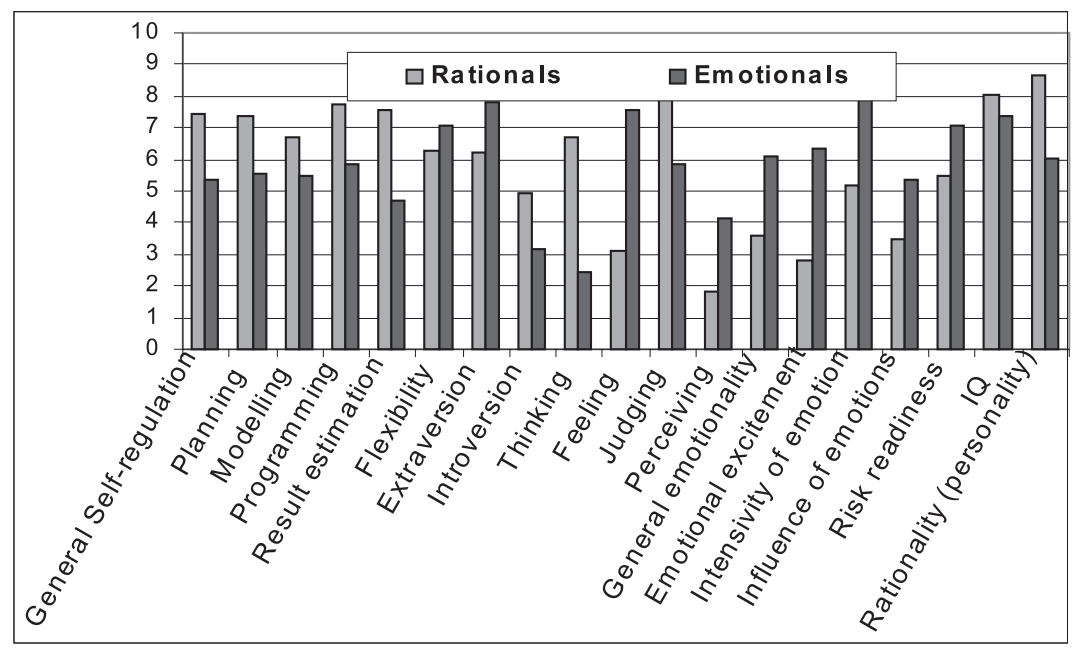

Figure 2. Comparisons between the extreme emotional and rational subject groups 
The results revealed complex sets of self-regulatory characteristics on which the two groups differ. Compared to emotional subjects, rational subjects are characterized by significantly high scores on the general level of self-regulation $(t=3,95 ; p<0,01)$, the self-regulation processes of goal planning $(\mathrm{t}=4,37 ; \mathrm{p}<0,05)$, the programming of actions $(t=3,12 ; \mathrm{p}<0,01),(\mathrm{t}=3,33 ; \mathrm{p}<0,01)$, result estimation and the modelling of significant conditions $(t=2,11 ; \mathrm{p}<0,01)$. They had significantly lower scores than emotional subjects on the development of flexibility in self-regulation $(t=-1,77 ; \mathrm{p}<0,01)$. The two groups also differ significantly on personality characteristics as measured by the Keirsey scale. The rational subjects scored higher than the emotional subjects on introversion $(t=1,96 ; \mathrm{p}<0,05)$, thinking $(\mathrm{t}=2,35 ; \mathrm{p}<0,001)$, and judg ing $(t=2,57 ; p<0,001)$. The rational subjects scored significantly higher than the emotional subjects on intelligence $(t=-3,32 ; p<0,05)$ and lower than the emotional subjects on risk-readiness $(t=-2,57 ; \mathrm{p}<0,01)$.

On the Ilyin questionnaire, emotional subjects scored significantly higher than rational subjects on general emotionality $(t=-8,11 ; \mathrm{p}<0,01)$ and the emotionality components of excitement $(t=-7,9 ; p<0,01)$, in-

Table 2

Self-regulation typologies for the rational and emotional subject groups

\begin{tabular}{|c|c|c|c|}
\hline \multirow{2}{*}{ 产 } & \multirow{2}{*}{$\begin{array}{c}\text { Self- } \\
\text { regulation } \\
\text { type }\end{array}$} & \multicolumn{2}{|c|}{ Personality characteristics } \\
\hline & & $\begin{array}{c}\text { Developed } \\
\text { self-regulation traits }\end{array}$ & $\begin{array}{c}\text { Dominant personality } \\
\text { characteristics }\end{array}$ \\
\hline \multirow{4}{*}{ 苂 } & $\begin{array}{l}\text { "Rational } \\
\text { planning" }\end{array}$ & $\begin{array}{l}\text { goal planning, general self- } \\
\text { regulation }\end{array}$ & $\begin{array}{l}\text { rational, introverted, sensory, } \\
\text { thinking, judging }\end{array}$ \\
\hline & "Rational & $\begin{array}{l}\text { modelling of significant condi- } \\
\text { tions, general self-regulation }\end{array}$ & $\begin{array}{l}\text { rational, introverted, sensory, } \\
\text { feeling, judging }\end{array}$ \\
\hline & $\begin{array}{l}\text { "Rational } \\
\text { program- } \\
\text { ming" }\end{array}$ & $\begin{array}{l}\text { programming of actions, } \\
\text { general self-regulation }\end{array}$ & $\begin{array}{l}\text { rational, introverted, intuiti- } \\
\text { tive, thinking, judging }\end{array}$ \\
\hline & $\begin{array}{l}\text { "Rational } \\
\text { evaluating" }\end{array}$ & $\begin{array}{l}\text { evaluation of results, general } \\
\text { self-regulation }\end{array}$ & $\begin{array}{l}\text { rational, extraverted, sensory, } \\
\text { thinking, judging }\end{array}$ \\
\hline ఫేँ్ & $\begin{array}{l}\text { "Emotional- } \\
\text { extraverted" }\end{array}$ & $\begin{array}{l}\text { flexibility, modelling of sig- } \\
\text { nificant conditions }\end{array}$ & $\begin{array}{l}\text { emotional, rational, intuitive, } \\
\text { extraverted, feeling, impulsive }\end{array}$ \\
\hline 兽 & $\begin{array}{l}\text { "Emotional- } \\
\text { neurotic" }\end{array}$ & $\begin{array}{l}\text { flexibility, goal planning, } \\
\text { programming of actions. }\end{array}$ & $\begin{array}{l}\text { Emotional, sensory, extraverted, } \\
\text { feeling, impulsive, risk-ready }\end{array}$ \\
\hline
\end{tabular}

tensiveness $(t=-6,74 ; p<0,001)$, and the influence of emotion on communication and activity. At the same time, the mean rationality level of the rational group was significantly higher than in emotional group $(\mathrm{t}=-2,57 ; \mathrm{p}<0,001)$.

Based on the above results, a regulation-personality typology of the rational and emotional subject groups with respect to decision making was constructed. Using cluster analysis, typical regulation profiles of rational and emotional subjects were distinguished, and typical personality and cognitive traits were described. In partiqular, 4 regulation-personality types were distinguished: "rationally-planning", "rationally-programming", "rationally-modelling" and "rationally-esteeming" and characterized in terms of developed self-regulation and personality traits.

For the 57 high rationality subjects, four self-regulation profiles or clusters were distinguished. Along with the proportion of variance they accounted for these clusters are: 1) "rational evaluating" (36,8\%), 2) "rational programming" $(33,4 \%), 3)$ "rational modelling" (14,03\%), and 4) "rational planning" (15,77\%). Each of these profiles is associated with a specific complex of personality characteristics, emotionality characteristics, risk-readiness, and intelligence (see Table 2). (44\%). These results are illustrated in Figure 3.

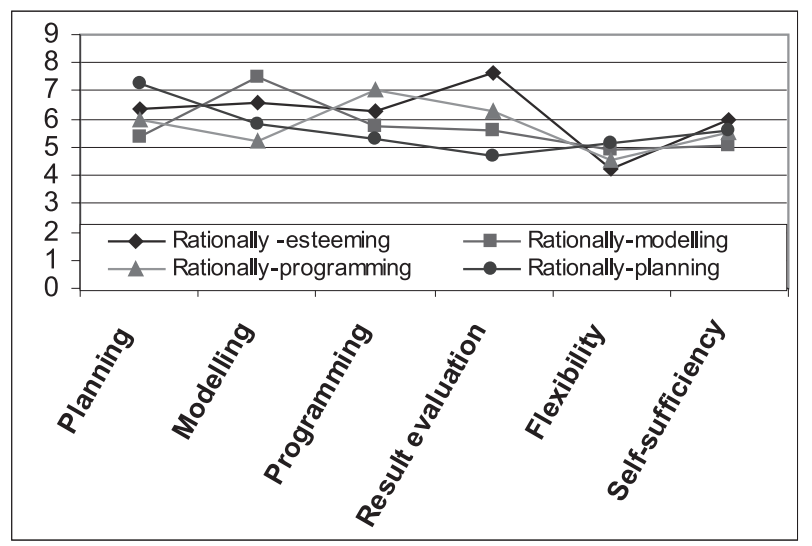

Cluster 1 - "rationally-esteeming" type (36,8\%), cluster 2 - "rationallyprogramming" type $(33,4 \%)$, cluster 3 -"rationally-modeling" type

$(14,03 \%)$, cluster 4 - "rationally-planning" type $(15,77)$.

Figure 3. The self-regulation profiles of rational subjects 


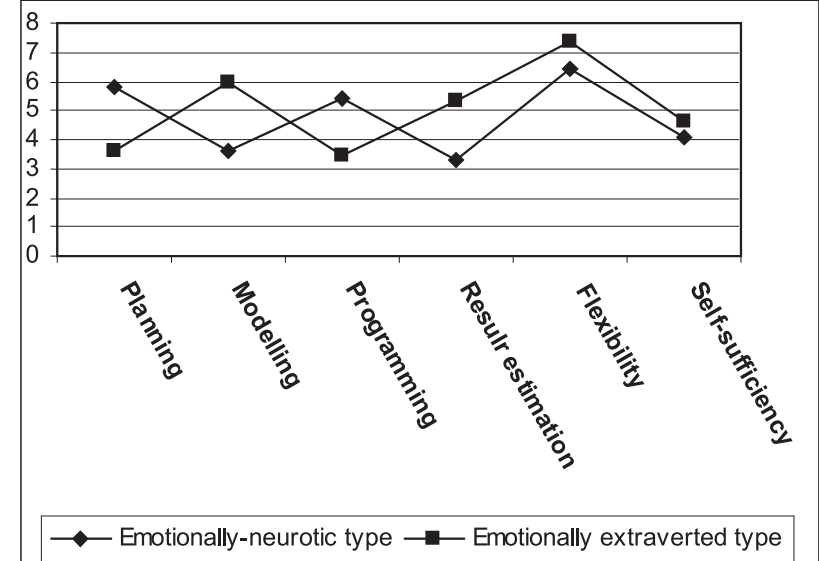

Cluster 1 - "emotionally-neurotic" type (56\%),

cluster 2 - "emotionally-extraverted" type (44\%)

Figure 4. The self-regulation profiles of emotional subjects

For the 50 high emotionality subjects, two typical profiles of selfregulation, based on Morosanova and Konoz (2000), were distinguished. Along with the proportion of variance accounted for, these are: 1) "emotional-neurotic," which is characterized by low scores on general selfregulation, developed flexibility, planning, and programming (56\%), and 2) "emotional-extraverted," which is characterized by high scores on general self-regulation, regulation flexibility, and modelling (44\%).

These results are illustrated in Figure 4.

Each self-regulation profile was described in terms of emotionality, risk-readiness, and intelligence. We also identified specific personality types for each group according to the Keirsey scale. Specifically, In the high emotionality group, $46 \%$ of the subjects were classified as "intuitivefeeling," and 30\% were identified as "sensory-impulsive". In the high rationality group, $44 \%$ of the subjects were classified as "sensory-planning" and $31 \%$ as "intuitive-rational".

Thus, the present research allows us to conclude that subjects who take a highly rational approach to decision making are characterized by different personality traits than subjects who take a highly emotional approach to decision making. The high rationality group obtained high scores on the personality traits of introversion, thinking, and perceiving, and they tended to be classified as "sensory-planning" and "intuitive-rational." The high emotionality group obtained high scores on extraversion, feeling, and impulsiveness and tended to be classified as "sensory-impulsive and "intuitive-feeling."

In the regulation-personality typology, a specific group of emotional subjects is worthy of special attention. This group, labelled emotionalextraverted, is characterized by a high level of conscious self-regulation, high rationality, and high emotionality. This clustering of traits suggests that conscious self-regulation allows emotional subjects to compensate for their emotionality in decision making by making their choices more rationally. The results show that rationality and emotionality are both related to self-regulation in the context of decision making.

\section{Specific connections between individual psychological}

\section{traits and the rationality of decision making}

We discovered significant and strong positive correlations between rational decision making and the self-regulation of goal planning $(r=0,27$; $\mathrm{p}<0,01)$, the programming of actions $(\mathrm{r}=0,33 ; \mathrm{p}<0,01)$, the modelling of significant conditions $(r=0,35 ; p<0,01)$, the estimation of results $(r=0,39 ; p<0,01)$, the general level of self-regulation $(r=0,47 ; p<0,001)$, and general intelligence $(\mathrm{r}=0,31 ; \mathrm{p}<0,05)$, as well as the personality traits of rationality $(\mathrm{r}=0,61 ; \mathrm{p}<0,001)$, thinking $(\mathrm{r}=0,79 ; \mathrm{p}<0,001)$, judging $(r=0,6 ; p<0,001)$, and introversion $(r=0,24 ; p<0,05)$.

Rational decision making correlated significantly and negatively with feeling $(\mathrm{r}=-0,77 ; \mathrm{p}<0,001)$, impulsiveness $(\mathrm{r}=-0,6 ; \mathrm{p}<0,001)$, risk-readiness $(r=-0,25 ; p<0,01)$, general emotionality $(r=-0,31$; $\mathrm{p}<0,01)$, emotional excitement $(\mathrm{r}=-0,28 ; \mathrm{p}<0,01)$, emotional intensiveness $(\mathrm{r}=-0,44 ; \mathrm{p}<0,001)$, and the influence of emotions on communication and activity $(r=-0,29 ; p<0,01)$. Finally, there was a significant negative correlation rationality in decision making, and emotionality $(\mathrm{r}=-0,58 ; \mathrm{p}<0,001)$.

To provide a more detailed description of the aforementioned connections, a factor analysis was performed using the principal components method and a Varimax rotation. This analysis led to a simplified model of rationality involving three separate factors representing personality, self-regulation, and cognition. 
The first bipolar factor, labelled "Rational Personality," accounted for $28,65 \%$ of the total variance. The significant strong positive loadings were for the traits of rationality in decision making, thinking, judging, and introversion; the significant negative loadings were for feeling and perceiving.

The second factor, named "Rational Self-Regulation," accounted $15,60 \%$ of the total variance. The significant positive loadings were for rationality in decision making, general self-regulation, goal planning, programming of actions, modelling, and estimation of results; the one significant negative loading was for the emotionality of decision making.

The third factor, named "Rational Cognition," accounted for 11,6\% of the total variance. The significant positive loadings were for the rationality of decision making and general intelligence; the significant negative loadings were for emotional intensiveness, emotional excitement, extraversion, and risk-readiness.

These three factors which are activated by the self-regulation system, can be viewed as resources that can be drawn upon to help one make rational decisions.

In the final stage of our research, we used regression analysis to distinguish the specific self-regulatory, personality, and cognitive traits that determine rational decision making. The positive determinants of rational decision making which were identified by the regression analysis and include the traits of general rationality $(B=0,64 ; p<0,01)$, general self-regulation $(B=0,61 ; p<0,001)$, thinking $(B=0,57 ; p<0,001)$, judging $(B=0,55 ; p<0,001)$, and general intelligence $(B=0,42 ; p<0,05)$. The single negative determinant was emotional intensiveness $(B=-0,41$; $\mathrm{p}<0,01)$

In summary, it was established that high general levels of self-regulation and rationality, along with well-developed cognitive abilities and the personality traits of thinking and judging, can facilitate rational decision making in situations such as political voting. On the other hand, emotional intensiveness negatively affects rational decision making.

\section{Conclusions}

1. In terms of self-regulation, rational decision making is defined as the adequate evaluation of alternatives involving personal goals, the search for needed information, the analysis of relevant external and internal con- ditions, consideration of the methods and tools needed to implement the decision, and the evaluation of the consequences of the decision.

2. The rationality of decision making is determined by a complex of self-regulatory, personality, and cognitive traits which influence rationality generally. High emotional intensiveness has a negative influence on the rationality of decision making.

3. The political voting model allows one to elicit the criteria for rational or emotional choices. In our application, subjects chose between two political candidates, one projecting a rational image and the other an emotional image. The rationality and emotionality of the subjects' decisions were assessed by self-reports of their decision process. Application of the model allowed two groups of subjects to be distinguished, one characterized as extremely rational and the other as extremely emotional in decision making.

4. Various differences between the rational and emotional groups in terms of self-regulation, personality, and cognitive traits were uncovered. In comparison to subjects in the high emotionality group, subjects in the high rationality group were characterized as significantly higher in general self-regulation, conscious goal planning, programming of actions, modelling significant conditions, and estimating consequences In terms of personality, the more rational subjects scored higher on thinking, judging, introversion, general rationality, and general intelligence. The more emotional subjects scored lower than the more rational subjects on general self-regulation but higher on flexibility. The more emotional subjects also scored higher on extraversion, impulsivity, general emotionality, and risk-readiness, but lower on general intelligence and general rationality.

5. The self-regulation typology has specific expressions in the high rationality and the high emotionality groups. For the high rationality group, four subtypes were distinguished: "rational programming," "rational planning," "rational estimation," and "rational modelling." For the high emotionality group, there were two types of regulation: "emotional-extraverted" and "emotional-neurotic." Each subtype is associated with a specific complex of self-regulatory, personality, and cognitive characteristics.

6. General self-regulation plays an important role in decision making, particularly in the context of political voting. The self-regulation system mediates the influence of cognitive and personality characteristics on decision making and increases its rationality. 


\section{References}

Abell, P. (ed.) (1991). Rational Choice Theory. Aldershot, Vermont: Edward Elgar.

Edwards, W. (1954). The theory of decision making. Psychological Bulletin, 51. P. $380-417$

Indina, T. (2008). Personality and regulation determinants of rationality in decision making situations. In Abstract book of 14th European Conference on Personality Tartu, Estonia, July 16-20, 2008. Tartu University Press.

Indina, T.A., and Morosanova, V.I. (2006). Personality types and individual differences in decision making. In 13th European conference on personality (July 22-26, Athens, Greece): Conference program and abstracts book. Athens. P. 236.

Indina, T., and Morossanova, V, (2008). Personality and regulation determinant of rational decision making in political voting situations. International Journal of Psychology, Abstracts of the XXIX International congress of psychology, Berlin, Germany, July 20-25, 2008. Psychology press. P. 678.

Kahneman, D., Slovic, P., and Tversky, A. (eds.). (1982). Judgment under Uncertainty: heuristics and biases. Cambridge University Press.

Kahneman, D., and Tversky A. (1973). On the Psychology of Prediction. Psychological Review, 80, July. P. 237-251.

Keirsey, D. (1989). Portraits of temperament. Del Mar, CA: Prometheus Nemesis Book Co.

Konopkin, O.A. (1995). Psikhicheskaya samoregulyatsia proizvolnoi aktivnosti cheloveka: strukturno-funktsionalnyi aspekt [Psychic self-regulation of voluntary activity (structure-functional aspect)]. Voprosy psikhologii, 1. P. 5-12.

Konopkin, O.A., and Morossanova, V.I. (1989). Stilevye osobennosti samoregulyatsii deyatel'nosti [Style peculiarities of activity self-regulation]. Voprosy psikhologii, 5. P. $18-26$

Kornilova, T.V. (2006). Psikhologia riska i prinyatia reshenij [Psychology of risk and decision making]. Moskva.

Morossanova, V.I. (1991). Stilevyje osobennosti samoregulatsii lichnosti [Style peculiarities of personality self-regulation]. Voprosy Psykhologii, 1. P. 121-127.

Morossanova, V.I. (1995). Individual'nyj stil' samoregulatsii v proizvol'noi aktivnosti cheloveka [Individual style of self-regulation in humans' voluntary activity] Psykhologicheskij zhurnal, 4. P. 26-35.

Morossanova, V.I. (1998). Individual'nyj stil' samoregilatsii: fenomen, struktura funktsii $v$ prozvol'noi aktivnosti cheloveka [The individual style of self-regulation: The phenomenon, structure and function in human voluntary activity]. Moskva: Nauka.

Morossanova, V.I. (2002). Lichnostnyje aspekty samoregulatsii proizvol'noi aktivnosti cheloveka [Personal aspects of self-regulation of human voluntary activity] Psychologicheskij zhurnal, 6. P. 5-17.
Morossanova, V.I. (2003) Extraversion and Neiroticism: The typical profiles of Self-regulation. European Psychologist, 4. P. 279-288.

Morossanova, V.I. (2006). Stil samoregulyatsii povedeniya [Style of self-regulation of behavior]. Methodological handbook. Moskva: Cogito-centr.

Morossanova, V.I., and Konoz, E.M. (2000). Stilevaja samoregulatsiya pevedenia cheloveka [Stylistic self-regulation of human behavior]. Voprosy Psykhologii, 2. P. 118127.

Simon, H. (1959). Theories of Decision Making in Economics and Behavioral Science. American Economic Review, 49.

Tversky, A., and Kahneman, D. (1986). Rational Choice and the Framing of Decisions. J. Business, 59, 4. P. 251-278. 